\title{
A SZERZŐI JOG ALKALMAZÁSI KÖRÉBEN SZÜKSÉGES KOMPETENCIÁK
}

\section{REDL KÁROLY}

\section{Tartalmi összefoglaló}

A könyvtáros szakma gyakorlásához szükséges kompetenciák körébe a jogi ismeretek átfogó ismerete és alkalmazni tudása is beletartozik. A kompetencia fogalmának több szempontú elemzése után a szerzö áttekinti az elmúlt évszázadok gyakorlatát a szellemi alkotások védelmének szabályozásáról. A hatályos magyar szerzöi jogi szabályozás (1999. évi LXXVI. tv.) fontosabb rendelkezéseit tételesen is ismerteti és kommentálja. Felhívja a könyvtárosok figyelmét a szerzöi jogi kérdések ismeretére és alkalmazásuk elengedhetetlen fontosságára.

https://doi.org/10.46280/KOMPKONF.2020.Redl

A kompetencia latin eredetű szó (competentia), eredeti jelentése illetékesség. A különböző szakmákban, így a könyvtáros szakmában is, általános tapasztalat, hogy ez az illetékesség, a szakma műveléséhez szükséges tudás folyamatosan újabb és újabb elemekkel bővül. Gondoljunk csak arra a technikai fejlődésre, ami az elmúlt néhány évtizedben végbement. A hetvenes évek végén egy könyvtárban a legnagyobb technikai kihívást a villanyírógépek használata jelentette. A napjainkban diplomát szerzett könyvtárosok számára a villanyírógép legfeljebb egy egzotikus múzeumi tárgy, használatának ismerete semmiféleképpen nem tartozik a könyvtáros szakma gyakorlásához szükséges kompetenciák közé. Hol vagyunk ma már ettől, amikor gyakorlatilag számítástechnikai eszközök nélkül szinte egyetlen könyvtárosi munkafolyamat sem elképzelhető.

Hasonló a helyzet a könyvtáros szakma ellátásához szükséges jogi ismeretek egyre bővülő körével is. Elég, ha a szakmánkat ért legújabb kihívásra, a GDPR (General Data Protection Regulation), magyarul Általános Adatvédelmi Rendelet új rendelkezéseinek megismerésére és alkalmazására gondolunk.

Talán sikerült ezzel a néhány példával érzékeltetni, amit mindannyian napról napra újra átélünk, hogy munkánk ellátásához újabb és újabb tudást kell a már megszerzettek mellé elsajátítanunk. Jól tudjuk, hogy egyre nagyobb értéke van annak, ha valaki többször meg tudja újítani tudását, és az új helyzetekben képes a tanultakat alkalmazni. Bonyolítja a helyzetet az is, hogy a kompetencia fogalma is folyamatosan változik, tartalma folyamatosan újabb és újabb elemekkel gazdagodik.

A kompetencia fogalma a mai köznyelvben a következőket jelenti:
- illetékesség,
- jogosultság,
- hozzáértés,
- hatáskör,
- szakértelem,
- alkalmasság. 
A szakirodalomban így is meghatározzák a kompetencia fogalmát: a kompetencia képességet jelent komplex feladatok adott kontextusban történő sikeres megoldására. A fogalom magában foglalja az ismeretek mobilizálását, kognitív és gyakorlati képességeket, a szociális és magatartási komponenseket és attitüdöket, az érzelmeket és az értékeket egyaránt.

Ha tehát arra a kérdésre keressük a választ, hogy a könyvtárosnak a szerzői jog alkalmazása körében milyen kompetenciákra van szüksége, akkor mindenképpen szüksége van az alábbi kompetenciákra:

- intellektuális kompetenciákra,

- módszertani kompetenciákra.

Kicsit bővebben kifejtve meg kell állapítanunk, hogy az intellektuális kompetenciák körébe tartozik a problémamegoldás képessége. A problémamegoldás a következő elemekből áll:

probléma azonosítása,

- a probléma megértése,

- a probléma reprezentációja,

- a problémamegoldása,

- az eredmény kommunikálása.

Már az első pont, a probléma azonosítása is számos további ismeretet igényel, melyek közül az egyik a jogrendszer ismerete. A hatályos jogi szabályok ismerete nélkül már a probléma azonosítása is lehetetlen.

Mielőtt részletesen vizsgálnánk a hatályos magyar szerzői jogot, célszerű a jog fogalmával megismerkednünk. A ,jog” mint jogszabály azt a magatartási normát jelöli, amelynek érvényesülését az állami kényszerhatalom biztosítja - akár azért, mert a kérdéses magatartási szabályt maga az állam alkotta, vagy pedig azért, mert az általánosan elfogadott magatartási szabályt (szokásjogot) az állam elismeri.

Úgy gondolom, hogy a szerzői jogi kérdések szabályozásának megértéséhez, a problémák azonosításához, megértéséhez vezető legjobb módszer, ha megismerjük azt az utat, amit a szerzői jogi kérdések szabályozása a kezdetektől napjainkig megtett. Ezért a következőben szeretném nagyon röviden bemutatni, hogy a szerzői jog nem egyetemes vagy időtlen intézmény. A szerzői jog az elmúlt ötszáz év kommunikációs környezetének terméke. Ennek megfelelően a különböző korszakokban különböző módon tekintettek a szerzői jogi kérdésekre, az ezekkel kapcsolatos társadalmi megítélés, állami szabályozás folyamatosan változott. Lássuk tehát a következőkben, hogyan változott a szellemi alkotások társadalmi megítélése.

Ismert tény, hogy a klasszikus antik szerzők (pl. Vergilius, Cicero, Seneca, Homérosz) műveit az esetek többségében nem a szerzők kézirataiból, hanem különböző kézírásos másolatokból ismerjük. Ezekkel a kéziratos másolatokkal kapcsolatban nem vethető fel a jogtalanság kérdése, hiszen ebben a korszakban a kézírással készülő másolatkészítés nehéz és időigényes munkáját az eredeti szerző munkássága előtti tiszteletadásnak tekintették. Az utókor hálás lehet ezeknek az embereknek, akik vették a fáradtságot és másolataik révén ránk hagyományozták az antik szerzők műveit. 
A 7. század körül kialakult iszlám kultúra sem tekintette a szellemi alkotást olyannak, amihez vagyoni jogok kapcsolódtak volna. Az iszlám törvények szerint a tolvaj, aki könyvet lopott, nem a lopásért járó szokásos büntetést - a kézlevágást - kapta. Ugyanis az iszlám törvény szerint a tolvaj nem akarta a könyvet, mint papírból és tintából álló tárgyat ellopni, hanem a könyvben lévő gondolatokat akarta elsajátítani. Ök úgy tekintették, hogy a papírral és tintával szemben a gondolatok nem voltak vagyontárgyak.

Az Újszövetség is sajátosan fogalmaz akkor, amikor a tudást Isten ajándékaként határozza meg. Máté evangéliuma szerint (Mt. 10:8) Jézus, amikor tanítani küldte az apostolokat, ezt mondta nekik: „Ingyen kaptátok, ingyen is adjátok.” Tehát a tudást, a szellemi alkotást nem tekintették árucikknek. Sok évszázaddal később sem változott alapvetően a társadalmi megítélése a szellemi alkotásoknak. Friedrich Schiller (1759-1805) A föld felosztása címü versében ezt írja 1780-ban (részlet):

Régen túl voltak már az osztozáson;

S jön a költö - ki tudja, merre járt.

Jaj, nem volt semmi szabad a világon,

És már minden gazdát talált.

„Jaj nekem! hát csak engem feledtél el,

Leghübb gyermeked, irgalmatlanul?"

Így kiáltott keservesen szegény fel,

S Zeusz trónja elé borul.

„Mit tegyek? Földem - szólt Zeusz - kimértem:

Másé már erdö, piac, dús határ.

De ha velem akarsz élni az égben:

Ahányszor csak jössz, mindig nyitva vár.,

(Ford.: Rónay György)

A vers egy olyan társadalmat ábrázol, ahol a szellemi alkotómunkát, az ahhoz való tehetséget égi adománynak tekintik, amely szerint a szellemi alkotás nem szorul pénzügyi támogatásra, ellenszolgáltatásra. Természetesen az általános társadalmi vélekedés és a szerzők véleménye személyes érdeke nem esett egybe.

Daniel Defoe (1659-1731) már másként vélekedik az író munkájának értékéről: „Egy könyv a Szerzö tulajdona, invencióinak gyermeke, elméjének porontya, ha eladja tulajdonát, akkor a vásárló jogává válik."

Lényegileg ezen az állásponton volt Beaumarchais (1732-1799) is: „A színházak elöcsarnokaiban az emberek arról beszélnek, hogy nem illó dolog az ismertséget keresö szerzöknek a mindennapi szükségleteikért küzdeniük. Az igaz, hogy az ismertség felmentő ok, de az emberek elfelejtik azt, hogy a természet arra kárhoztatott minket, hogy 365-ször ebédeljünk, hogy tudjuk élvezni a sikert egy éven át." 
Mindkét szerző megfogalmazza a szellemi alkotás árucikk jellegét. El akarták ismertetni, hogy a szerzői müvel kapcsolatban vagyoni jogok keletkeznek, aminek jövedelméből a szerzőknek részesülniük kell.

Az első angolszász, modern átfogó szerzői jogi törvény, ami a szerzők vagyoni jogait is rendezte, a Statute of Anne (Anna Királynö Törvénye, 1710. április 10.) volt.

A törvény két új fogalmat vezetett be:

- a szerző, szerzői jogának tulajdonosa,

- a kiadott müvek védelmi ideje határozott idejü.

A törvény legfontosabb vívmánya az volt, hogy a szerzőknek 14 éves határozott idejü felügyeleti jogot biztosított (ami a lejárati idő után újabb 14 évre meghosszabbítható volt).

Az egyes könyvkiadók egyeduralmának megtörése érdekében 21 évre korlátozták a kiadók korábbi örökös jogát. Figyelembe vette az alkotó, a versenytársak, a befektetők, a közönség érdekeit is.

Könyvtáros szempontból egyébként a Statute of Anne érdekessége, hogy elrendelte a kiadott könyv 9 példányának (másolatának) letétbe helyezését meghatározott könyvtárakba. Természetesen nagyon hamar a kiadók és nyomdák is megfogalmazták speciális érdekeiket. Ilyen volt például a kalózkiadásokkal kapcsolatos érvelés az 1770-es évekből: A könyv nem egy ideális tárgy... „Papírból készült tákolmány, amire a gondolati szimbólumokat nyomtatják. A könyv nem tartalmaz gondolatokat. Ezeknek a szöveget megértö olvasónak az agyában kell keletkezniük. Olyan árucikk, amit kökemény pénzért állítanak elö. Minden kormány kötelessége korlátozni a gazdaságnak a kiáramlását, ennélfogva ösztönözni a külföldi müalkotások reprodukálását."

Két konkrét példa az Egyesült Államok 19. századi gyakorlatából:

- New Yorkban, Philadelphiában és Bostonban fantasztikus vagyonokat gyüjtöttek a kiadók brit szerzők jogosulatlan és ellentételezés nélküli kiadásából.

- A Harper's Monthly című lap kizárólag a brit magazinok példányaiból készített jogosulatlan másolatokból állt. (Érdekes adalék például, hogy 1843-ban Dickens Karácsonyi énekének egy példánya 6 centbe került az USA-ban, míg a szerző hazájában, Angliában 2 dollár 50 centbe.)

A Sherman and Johnson kiadó (USA) a következő ideológiával próbálta igazolni a kalózkiadás gyakorlatát: „Az angol irodalom teljes gazdagsága a miénk. Az angol szerzőség, mint életfontosságú levegö, ingyen jut el országunkba, adózás nélkül, akadály nélkül, sőt forditás szüksége nélkül, és a kérdés ez: adóztassuk-e meg, sígy állitsunk akadályt a szellemi és morális fény terjedése elé? Építsünk-e gátat, hogy a tudás folyóinak áradását akadályozzuk?”

Az érvelés jól mutatja, hogy a kiadók, nyomdák gazdasági érdeke, hogyan igyekszik befolyásolni a szellemi alkotásokra vonatkozó jogi viszonyokat.

Az előző példákból is jól látható, hogy a szellemi alkotások jogi problémái országokon átívelő módon is megjelentek, ezért nem csoda, hogy ezekkel a jogokkal nem csak egy-egy nemzetállam jogalkotása, hanem nemzetközi egyezmények is foglalkoznak. Ilyen nemzetközi egyezmény például az Emberi Jogok Egyetemes Nyilatkozata (ENSZ, 1948) is. 
A Nyilatkozat 27. cikkében így fogalmaz:

1. Minden személynek joga van a közösség kulturális életében való szabad részvételhez, a müvészetek élvezéséhez, valamint a tudomány haladásában és az abból származó jótéteményekben való részvételhez.

2. Mindenkinek joga van minden általa alkotott tudományos, irodalmi és müvészeti termékkel kapcsolatos erkölcsi és anyagi érdekeinek védelméhez.

Az Emberi Jogok Egyetemes Nyilatkozata mellett más nemzetközi egyezmények is foglalkoznak a kérdéssel: pl. az Emberi Jogok Európai Egyezménye, a Gazdasági, Szociális és Kulturális Jogok Nemzetközi Egyezségokmánya vagy a Polgári és Politikai Jogok Nemzetközi Egyezségokmánya.

Több olyan nemzetközi szervezet is müködik, amelynek feladata a szellemi alkotások jogának, a szerzőket megillető jogoknak a szabályozása, védelme, ilyen pl. a Szellemi Tulajdon Világszervezete vagy az UNESCO is.

A fentiekben talán sikerült bemutatni, hogy a szellemi alkotások joga, a szerzőket megillető jogok szabályozása időről időre változott és napjainkban is változik. Nem volt ez másképpen Magyarországon sem. Mielött rátérnék a hatályos szerzői jogi törvény ismertetésére, érdemes egy villanás erejéig a szerzői jog hazai történetét feleleveníteni.

A szerzői joghoz kapcsolódóan elöször az 1872. évi VIII. tc., az ipartörvény hozott rendelkezéseket; ezek szerint megszüntették a nyomdai üzlet privilégiumokhoz, tehát engedélyhez való kötöttségét. Az 1875-ös kereskedelmi törvényben (1875. évi XXXVII. tc.) a kiadói jogot szabályozták. Az 515. \$ szerint a kiadói szerződés olyan ügylet, mely által a kiadó a kész vagy a készítendő irodalmi, műszaki vagy művészeti munka többszörözésére, közzétételére és forgalomba helyezésére a szerzőtől vagy jogutódjától kizárólagos jogot szerez. Később átfogó törvények születtek a szerzői jogról (1884. XVI. törvénycikk, illetve az 1969. évi III. törvény).

A hatályos magyarországi jogszabályok közül a leglényegesebb az 1999. évi LXXVI. törvény a szerzői jogról. Ez a törvény védi a szellemi alkotásokat és egyben meg is jelöli a védendő alkotások körét. Természetesen a $113 \$$-ból álló törvény részletes bemutatására ez a dolgozat nem alkalmas, azonban a törvény néhány főbb rendelkezésének felidézése indokolt lehet:

1. $\$$ (1) Ez a törvény védi az irodalmi, tudományos és müvészeti alkotásokat.

(2) Szerzői jogi védelem alá tartozik - függetlenül attól, hogy e törvény megnevezi-e az irodalom, a tudomány és a müvészet minden alkotása. Ilyen alkotásnak minősül különösen:

a) az irodalmi (pl. szépirodalmi, szakirodalmi, tudományos, publicisztikai) mü

b) a nyilvánosan tartott beszéd

c) a számitógépi programalkotás és a hozzá tartozó dokumentáció (a továbbiakban: szoftver) akár forráskódban, akár tárgykódban vagy bármilyen más formában rögzitett minden fajtája, ideértve a felhasználói programot és az operációs rendszert is 
d) a szinmü, a zenés szinmü, a táncjáték és a némajáték

e) a zenemü, szöveggel vagy anélkül

f) a rádió- és a televiziójáték

g) a filmalkotás és más audiovizuális mü (a továbbiakban együtt: filmalkotás)

A törvény rögzíti azt is, hogy a szerzői jogi védelem keletkezése miként történik:

- Semmiféle hatósági eljárásra nincs szükség.

- A jogi védelem a mü keletkezésével egyszerre keletkezik.

A törvény meghatározza azt is, hogy mely szellemi alkotások nem részesülnek védelemben:

- Nem tartoznak e törvény védelme alá a jogszabályok, az állami irányítás egyéb jogi eszközei, a bírósági vagy hatósági határozatok, a hatósági vagy más hivatalos közlemények és az ügyiratok, valamint a jogszabállyal kötelezővé tett szabványok és más hasonló rendelkezések.

A törvény meghatározza azt a fö elvet, ami alapján megilleti a szellemi alkotást a jogi védelem, ez pedig az egyéni eredeti jelleg:

- A szerzői jogi védelem az alkotást a szerző szellemi tevékenységéből fakadó egyéni, eredeti jellege alapján illeti meg. A védelem nem függ mennyiségi, minőségi, esztétikai jellemzőktől vagy az alkotás színvonalára vonatkozó értékítélettől.

- Pl. müfordítás igen, de a nyersfordítás (szó szerinti) nem minősül egyéninek és eredetinek.

A szerzőt művével kapcsolatban személyhez füződő és vagyoni jogok is megilletik.

A szerző személyhez füződő jogai az alábbiak:

- A mű nyilvánosságra hozatalának a joga. A szerző határoz arról, hogy a műve nyilvánosságra hozható-e.

- A név feltüntetésének a joga. A szerzőt megilleti a jog, hogy művén szerzőként feltüntessék.

- A mü egysége védelmének joga. A szerző személyhez füződő jogát sérti művének mindenfajta eltorzítása, megcsonkítása, vagy a mü más olyan megváltoztatása vagy a müvel kapcsolatos más olyan visszaélés, amely a szerző becsületére vagy hírnevére sérelmes.

A szerző vagyoni jogai az alábbiak:

- A szerzőnek kizárólagos joga van a mủ egészének vagy valamely azonosítható részének anyagi formában és nem anyagi formában történő bármilyen felhasználására és minden egyes felhasználás engedélyezésére.

- A szerző engedélye szükséges a mü sajátos címének felhasználásához is.

- A szerzőt megilleti a műben szereplő jellegzetes és eredeti alak kereskedelmi hasznosításának és az ilyen hasznosítás engedélyezésének kizárólagos joga is.

- A szerzőt a mű felhasználására adott engedély fejében díjazás illeti meg, amelynek - eltérő megállapodás hiányában - a felhasználáshoz kapcsolódó bevétellel kell arányban állnia. A díjazásról a jogosult csak kifejezett nyilatkozattal mondhat le. 
A jogalkotó bizonyos méltánylást érdemlő esetekben szabad felhasználást engedélyez, ilyen például:

35. S (4) Nyilvános szolgáltatásokat nyújtó könyvtár, iskolai oktatás célját szolgáló [33. S (4) bek.] intézmény, muzeális intézmény, levéltár, valamint a közgyüjteménynek minősülö kép-, illetve hangarchivum a müröl másolatot készithet, ha az jövedelemszerzés vagy jövedelemfokozás célját közvetve sem szolgálja, és

a) tudományos kutatáshoz vagy archiváláshoz szükséges,

b) nyilvános könyvtári ellátás vagy a 38. \$(5) bekezdésében meghatározott felhasználás céljára készül,

c) megjelent mü kisebb részéröl, továbbá újság-vagy folyóiratcikkröl belső intézményi célra készül, vagy

(5) Könyvként kiadott mü egyes részei, valamint újság- és folyóiratcikkek az iskolai oktatás céljára egy-egy iskolai osztály létszámának megfelelö, illetve a köz- és felsőoktatási vizsgákhoz szükséges példányszámban többszörözhetők.

Azonban a törvény által engedélyezett, szabad felhasználás eseteiben is el kell végezni az ún. „háromlépcsős tesztet”.

33. S (2) A felhasználás a szabad felhasználásra vonatkozó rendelkezések alapján is csak annyiban megengedett, illetve dijtalan, amennyiben nem sérelmes a mü rendes felhasználására és indokolatlanul nem károsítja a szerzö jogos érdekeit, továbbá amenynyiben megfelel a tisztesség követelményeinek és nem irányul a szabad felhasználás rendeltetésével össze nem féró célra.

Érdekességként szeretném megemlíteni, hogy szerzői jogi kérdésekkel, e jogok megsértésével a Büntető Törvénykönyv (2012. évi C. törvény) is foglalkozik:

Szerzői vagy szerzői joghoz kapcsolódó jogok megsértése

385. S (1) Aki másnak vagy másoknak a szerzői jogról szóló törvény alapján fennálló szerzői vagy ahhoz kapcsolódó jogát vagy jogait vagyoni hátrányt okozva megsérti, vétség miatt két évig terjedő szabadságvesztéssel büntetendő.

(2) Az (1) bekezdés szerint büntetendö, aki a szerzői jogról szóló törvény szerint a magáncélú másolásra tekintettel a szerzőt, illetve a kapcsolódó jogi jogosultat megilletö üreshordozó dij, illetve reprográfiai dij megfizetését elmulasztja.

(3) A büntetés büntett miatt három évig terjedő szabadságvesztés, ha a szerzöi vagy szerzöi joghoz kapcsolódó jogok megsértését nagyobb vagyoni hátrányt okozva követik el.

(4) Ha a szerzői vagy szerzői joghoz kapcsolódó jogok megsértését

a) jelentős vagyoni hátrányt okozva követik el, a büntetés büntett miatt egy évtöl öt évig,

b) különösen nagy vagyoni hátrányt okozva követik el, a büntetés két évtól nyolc évig,

c) különösen jelentös vagyoni hátrányt okozva követik el, a büntetés öt évtöl tíz évig terjedő szabadságvesztés. 
(5) Nem valósítja meg az (1) bekezdés szerinti büncselekményt, aki másnak vagy másoknak a szerzői jogról szóló törvény alapján fennálló szerzői vagy ahhoz kapcsolódó jogát vagy jogait többszörözéssel vagy lehívásra történö hozzáférhetövé tétellel sérti meg, feltéve, hogy a cselekmény jövedelemszerzés célját közvetve sem szolgálja.

Az eddigiekkel azt igyekeztem bizonyítani, hogy a szerzői jogi kérdések helyes kezelése szerteágazó ismeretanyagot feltételez. A könyvtárosnak sokféle kompetenciára, illetékességre van szüksége. Fontos, hogy empátiával rendelkezzen a szerzői jogi kérdésekkel kapcsolatban, ismernie kell a hatályos jogszabályokat, azonosítania kell az esetlegesen felmerülő problémákat, kreatív módon meg kell találnia a problémamegoldásához szükséges lépéseket és nem utolsó sorban állandóan nyomon kell követnie a hatályos joganyag változásait. Hiszen, ahogy a bevezető gondolatokban láttuk, a szerzői jog nem egy állandó, változatlan jogterület, mert a gazdasági élet, a technikai fejlődés és a nemzetközi jogi környezet folyamatosan mozgásban tartja a hatályos magyar szerzői jogi szabályokat.

\section{Irodalom}

Az előadás PART Krisztina Katalin cikke alapján készült: A szerzői jogi szabályozás kialakulása Angliában, Németországban és az Egyesült Âllamokban. = Iparjogvédelmi és Szerzői Jogi Szemle. 1. (111.) 4. 2006. 140-153.

Redl Károly 39 éve dolgozik az Országgyülési Könyvtárban, jelenleg igazgatóhelyettesként. A Magyar Könyvtárosok Egyesületének alelnöke, az elnökségen belül a határon túli kapcsolatok felelöse. Jogi tanácsaival gyakran segíti az egyesületet. Az Országgyűlés elnöke által a Kárpát-medencei fiatal magyar könyvtárosok számára meghirdetett Könyvtár, ami összeköt program főszervezője. A Nemzeti Kulturális Alap Könyvkiadás Kollégiumának tagja. A Szinnyei József-díj szakmai bizottságának elnöke. 